Chem. Pharm. Bull.

32( 2) $767-772(1984)$

\title{
Inhibition of Aldose Reductase by $3^{\prime}, 4^{\prime}$-Dihydroxyflavones
}

\author{
JUn OKUda, ${ }^{*, a}$ ICHITOMO MiWa, ${ }^{a}$ KAZUHIRo INAGAKI, ${ }^{a}$ \\ TOKUNARU HORIE, ${ }^{b}$ and MitSURU NAKaYAMA ${ }^{c}$ \\ Department of Clinical Biochemistry, Faculty of Pharmacy, Meijo University, ${ }^{a}$ Yagoto \\ Urayama, Tempaku-cho, Tempaku-ku, Nagoya 468, Japan, Department of \\ Applied Chemistry, Technical College of Tokushima University, ${ }^{b}$ \\ Minamijosanjima-cho, Tokushima 770, Japan, and Department \\ of Chemistry, Faculty of Science, Hiroshima University, \\ Higashisenda-machi, Naka-ku, Hiroshima 730, Japan
}

(Received June 9, 1983)

\begin{abstract}
A series of $3^{\prime}, 4^{\prime}$-dihydroxyflavones was assayed in vitro for inhibition of lens aldose reductase which has been implicated in the pathogenesis of sugar cataract. All the compounds tested were shown to be potent inhibitors of aldose reductase and $3^{\prime}, 4^{\prime}$-dihydroxy-5,6,7,8-tetramethoxyflavone (lens aldose reductase inhibitor 4, LARI 4), the most potent one, inhibited the enzymes from rat and bovine lenses by $50 \%$ at $3.2 \times 10^{-8}$ and $1.7 \times 10^{-7} \mathrm{M}$, respectively. Inhibition of the enzyme by $3^{\prime}, 4^{\prime}$-dihydroxyflavones was non-competitive with respect to both DLglyceraldehyde and reduced form of nicotinamide adenine dinucleotide phosphate. The inhibitory activities of $3^{\prime}, 4^{\prime}$-dihydroxyflavones against lens aldose reductase were $\mathrm{pH}$-dependent, being maximal around $\mathrm{pH}$ 7.0.
\end{abstract}

Keywords _ flavone; aldose reductase inhibitor; rat lens; bovine lens; aldose reductase; structure-activity relationship

Aldose reductase (EC 1.1.1.21) along with the coenzyme nicotinamide adenine dinucleotide phosphate (NADPH) catalyzes the reduction of aldose to alditol. This production of sugar alcohol has been implicated in the development of cataract in diabetes and galactosemia. ${ }^{1)}$ That aldose reductase plays a significant role under abnormal conditions such as diabetes makes the inhibition of aldose reductase a selective potential treatment for diabetic cataract.

In recent years, flavonoids have been reported to be potent inhibitors of this enzyme. ${ }^{2)}$ Quercitrin (3,5,7,3',4'-pentahydroxyflavone-3-rhamnoside) orally administered to diabetic animals inhibited D-glucitol accumulation in the lens, resulting in the prevention of the cataractous processes. ${ }^{3)}$

More recently, we $\mathrm{e}^{4)}$ have reported that axillarin $\left(5,7,3^{\prime}, 4^{\prime}\right.$-tetrahydroxy-3,6-dimethoxyflavone) and LARI 1 (6,3', $4^{\prime}$-trihydroxy-5,7,8-trimethoxyflavone) are the most potent inhibitors of aldose reductase among flavonoids tested so far and that they are at least 10 times more potent than quercitrin. We have also indicated that $3^{\prime}, 4^{\prime}$-dihydroxyflavones, flavones having two hydroxyl groups in a catechol orientation in ring $\mathrm{C}$, are more potent than the corresponding flavones having no hydroxyl, or having a monohydroxyl or methoxyl group in ring $\mathrm{C}$. Hence, the purpose of the present study was to examine the inhibitory activities of over twenty $3^{\prime}, 4^{\prime}$-dihydroxyflavones on rat lens aldose reductase (RLAR) and bovine lens aldose reductase (BLAR) as part of our search for more promising aldose reductase inhibitors. 
were purchased from Nakarai Chemicals Ltd., Kyoto, Japan. NADPH was from Oriental Yeast Co., Ltd., Osaka, Japan. DEAE-Sephacel and Sephadex G-75 were obtained from Pharmacia Fine Chemicals, Uppsala, Sweden. Mãtrex gel red A was purchased from Amicon Co., Lexington, MA, U.S.A. 3',4'-Dihydroxy-5,6,7-trisubstituted flavones, ${ }^{5}{ }^{\prime} 3^{\prime}, 4^{\prime}$-dihydroxy-5,7,8-trisubstituted flavones, ${ }^{5 c, 6)}$ and $3^{\prime}, 4^{\prime}$-dihydroxy-5,6,7,8-tetrasubstituted flavones ${ }^{7)}$ were isolated from various plants or chemically synthesized as reported previously.

Assay of Aldose Reductase Activity-Aldose reductase activity was assayed at $30^{\circ} \mathrm{C}$ by following the decrease of absorbance at $340 \mathrm{~nm}$ accompanying the oxidation of NADPH. Unless otherwise stated the reaction mixture contained $0.1 \mathrm{M}$ sodium phosphate buffer ( $\mathrm{pH} 6.2$, and optimum $\mathrm{pH}$ for the enzyme), $0.4 \mathrm{M}$ ammonium sulfate, $10 \mathrm{mM}$ DL-glyceraldehyde, $0.16 \mathrm{mM}$ NADPH and the enzyme in a total volume of $1.0 \mathrm{ml}$. The reaction was initiated by the addition of the substrate. One unit of the enzyme was defined as the amount catalyzing the oxidation of $1 \mu \mathrm{mol}$ of NADPH per min under the assay conditions used. The effect of inhibitor on the enzyme activity was determined by including in the reaction mixture $10 \mu \mathrm{l}$ of inhibitor solution at various concentrations $\left(10^{-6}-10^{-3} \mathrm{M}\right)$. Inhibitors were dissolved in propylene glycol to give a concentration of $10^{-3} \mathrm{M}$ and diluted to the desired concentrations with the solvent. Propylene glycol at $1 \%$ inhibited the enzyme by only $5 \%$ or less and did not affect the inhibitory potency of flavones. The inhibitory potency determined just after mixing of the enzyme and a flavone was the same as that observed after preincubation of the reaction mixture (containing an inhibitor, but not the substrate) at $30^{\circ} \mathrm{C}$ for $10 \mathrm{~min}$. Hence, the enzyme activity in the presence of an inhibitor was assayed without any preincubation throughout this study.

Reversibility of Inhibition of Aldose Reductase- - One $\mathrm{ml}$ of a solution containing $0.1 \mathrm{M}$ sodium phosphate buffer ( $\mathrm{pH}$ 6.2), $10^{-7} \mathrm{M}$ flavone ( $3^{\prime}, 4^{\prime}$-dihydroxy-5,6,7,8-tetramethoxyflavone (LARI 4, 26) or axillarin (8)), and BLAR (30 munits) was dialyzed at $4^{\circ} \mathrm{C}$ for $20 \mathrm{~h}$ against two changes of $500 \mathrm{ml}$ of $0.1 \mathrm{~m}$ sodium phosphate buffer (pH 6.2) containing $0.1 \mathrm{~mm}$ mercaptoethanol. Thereafter, an aliquot $(0.4 \mathrm{ml})$ of the impermeate was subjected to assay of the enzyme activity. The same procedure was applied to another solution (as a control) containing phosphate buffer and the enzyme, but not a flavone.

Purification of Aldose Reductase from Rat and Bovine Lenses_- Rat lenses were removed from eyes of rats of the Wistar strain weighing $200-250 \mathrm{~g}$. Bovine eyes were obtained from a local abattoir, and lenses were removed and frozen until needed. RLAR and BLAR were purified according to the method of Inagaki et al. ${ }^{8)}$ Briefly, a $40-75 \%$ ammonium sulfate fraction was subjected to chromatography on DEAE-Sephacel, followed by two column chromatographic steps, i.e. affinity chromatography using Mātrex gel red A and gel filtration on Sephadex G-75. RLAR and BLAR were purified over 380- and 12000-fold, respectively.

Determination of $\mathrm{IC}_{50}$ - The concentration of an inhibitor needed to elicit $50 \%$ inhibition $\left(\mathrm{IC}_{50}\right)$ was determined by the method described in ref. 9 . In this paper, $\mathrm{IC}_{50}$ values of inhibitors are expressed as their final concentrations in the reaction mixture.

\section{Results}

\section{Inhibitory Activities of Flavones against Aldose Reductase}

$\mathrm{IC}_{50}$ values of $3^{\prime}, 4^{\prime}$-dihydroxyflavones against RLAR and BLAR are shown in Table I. Flavones were classed into three groups $(1-11,12-20$, and 21-26) primarily according to the degree of substitution in ring $\mathrm{A}$.

1) $3^{\prime}, 4^{\prime}$-Dihydroxy-5,6,7-trisubstituted Flavones (1-11) - Methylation of the hydroxyl group at $C_{5}$ enhanced the inhibitory activity as shown by $6,3^{\prime}, 4^{\prime}$-trihydroxy-5,7dimethoxyflavone (4), 3',4'-dihydroxy-5,6,7-trimethoxyflavone (5), and 6,3',4'-trihydroxy3,5,7-trimethoxyflavone (10), which are more potent inhibitors than pedalitin (2), cirsiliol (3), and 5,6,3',4'-tetrahydroxy-3,7-dimethoxyflavone (7), respectively. $3^{\prime}, 4^{\prime}$-Dihydroxy-3,5,6,7tetramethoxyflavone (11), however, had almost the same potency as the corresponding phenolic compound (9,7-methylaxillarin). Methylation of the hydroxyl group at $\mathrm{C}_{6}$ increased or little affected the inhibitory potency. $\mathrm{We}^{4)}$ previously reported that the free hydroxyl group at $C_{7}$ in 5,6,7-trisubstituted flavones is favorable for the inhibitory activity (axillarin (8) $>7$ methylaxillarin (9)). This was confirmed in the present study by the fact that $5,6,7,3^{\prime}, 4^{\prime}-$ pentahydroxyflavone (1) and 5,6,7,3',4'-pentahydroxy-3-methoxyflavone (6) were more potent inhibitors than pedalitin (2) and compound (7), respectively. Methoxylation at $\mathrm{C}_{3}$ decreased or little affected the potency.

2) $3^{\prime}, 4^{\prime}$-Dihydroxy-5,7,8-trisubstituted Flavones (12-20)_- It appears that, as a whole, this series of flavones is similar in inhibitory activity to the corresponding $3^{\prime}, 4^{\prime}$-dihydroxy5,6,7-trisubstituted flavones. Methylation of the hydroxyl group at either $C_{5}$ or $C_{7}$ enhanced 
TABLE I. Aldose Reductase Inhibitory Activity of $3^{\prime}, 4^{\prime}$-Dihydroxyflavones

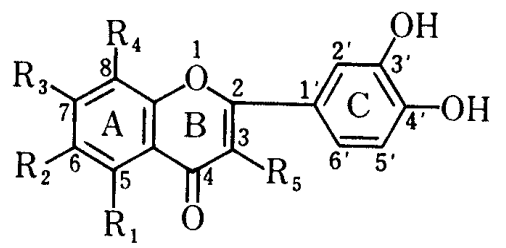

\begin{tabular}{|c|c|c|c|c|c|c|c|}
\hline & \multirow{2}{*}{$\mathrm{R}_{1}$} & \multirow{2}{*}{$\mathrm{R}_{2}$} & \multirow{2}{*}{$\mathrm{R}_{3}$} & \multirow{2}{*}{$\mathrm{R}_{4}$} & \multirow{2}{*}{$\mathrm{R}_{5}$} & \multicolumn{2}{|c|}{$\mathrm{IC}_{50}(\mathrm{M}) \times 10^{7}$} \\
\hline & & & & & & RLAR & BLAR \\
\hline 1 & $\mathrm{OH}$ & $\mathrm{OH}$ & $\mathrm{OH}$ & $\mathrm{H}$ & $\mathbf{H}$ & 2.0 & 4.6 \\
\hline 2 & $\mathrm{OH}$ & $\mathrm{OH}$ & $\mathrm{OMe}$ & $\mathrm{H}$ & $\mathrm{H}$ & 3.0 & 16 \\
\hline $3^{a)}$ & $\mathrm{OH}$ & $\mathrm{OMe}$ & $\mathrm{OMe}$ & $\mathrm{H}$ & $\mathrm{H}$ & 2.2 & 12 \\
\hline 4 & $\mathrm{OMe}$ & $\mathrm{OH}$ & $\mathrm{OMe}$ & $\mathrm{H}$ & $\mathbf{H}$ & 1.4 & 8.0 \\
\hline 5 & $\mathrm{OMe}$ & $\mathrm{OMe}$ & $\mathrm{OMe}$ & $\mathrm{H}$ & $\mathbf{H}$ & 0.90 & 5.8 \\
\hline 6 & $\mathrm{OH}$ & $\mathrm{OH}$ & $\mathrm{OH}$ & $\mathrm{H}$ & $\mathrm{OMe}$ & 0.58 & 3.7 \\
\hline 7 & $\mathrm{OH}$ & $\mathrm{OH}$ & $\mathrm{OMe}$ & $\mathrm{H}$ & $\mathrm{OMe}$ & 8.0 & 21 \\
\hline $8^{a)}$ & $\mathrm{OH}$ & $\mathrm{OMe}$ & $\mathrm{OH}$ & $\mathrm{H}$ & $\mathrm{OMe}$ & 0.30 & 1.8 \\
\hline $9^{a)}$ & $\mathrm{OH}$ & $\mathrm{OMe}$ & $\mathrm{OMe}$ & $\mathrm{H}$ & $\mathrm{OMe}$ & 3.5 & 8.5 \\
\hline 10 & $\mathrm{OMe}$ & $\mathrm{OH}$ & $\mathrm{OMe}$ & $\mathrm{H}$ & $\mathrm{OMe}$ & 3.0 & 16 \\
\hline 11 & $\mathrm{OMe}$ & $\mathrm{OMe}$ & $\mathrm{OMe}$ & $\mathrm{H}$ & $\mathrm{OMe}$ & 2.7 & 17 \\
\hline 12 & $\mathrm{OH}$ & $\mathrm{H}$ & $\mathrm{OH}$ & $\mathrm{OMe}$ & $\mathrm{H}$ & 2.8 & 14 \\
\hline 13 & $\mathrm{OH}$ & $\mathrm{H}$ & $\mathrm{OMe}$ & $\mathrm{OH}$ & $\mathrm{H}$ & 2.3 & 8.8 \\
\hline 14 & $\mathrm{OH}$ & $\mathrm{H}$ & $\mathrm{OMe}$ & $\mathrm{OMe}$ & $\mathrm{H}$ & 0.78 & 3.7 \\
\hline 15 & $\mathrm{OMe}$ & $\mathrm{H}$ & $\mathrm{OMe}$ & $\mathrm{OH}$ & $\mathrm{H}$ & 1.6 & 12 \\
\hline 16 & $\mathrm{OMe}$ & $\mathrm{H}$ & $\mathrm{OH}$ & $\mathrm{OMe}$ & $\mathrm{H}$ & 0.74 & 3.1 \\
\hline 17 & $\mathrm{OMe}$ & $\mathrm{H}$ & $\mathrm{OMe}$ & $\mathrm{OMe}$ & $\mathrm{H}$ & 0.45 & 2.7 \\
\hline 18 & $\mathrm{OH}$ & $\mathrm{H}$ & $\mathrm{OH}$ & $\mathrm{OMe}$ & $\mathrm{OMe}$ & 2.4 & 5.2 \\
\hline 19 & $\mathrm{OMe}$ & $\mathrm{H}$ & $\mathrm{OH}$ & $\mathrm{OMe}$ & $\mathrm{OMe}$ & 2.8 & 4.5 \\
\hline 20 & $\mathrm{OMe}$ & $\mathrm{H}$ & $\mathrm{OMe}$ & $\mathrm{OMe}$ & $\mathrm{OMe}$ & 1.7 & 5.4 \\
\hline 21 & $\mathrm{OH}$ & $\mathrm{OH}$ & $\mathrm{OH}$ & $\mathrm{OMe}$ & $\mathrm{H}$ & 1.2 & 4.2 \\
\hline 22 & $\mathrm{OH}$ & $\mathrm{OH}$ & $\mathrm{OMe}$ & $\mathrm{OMe}$ & $\mathrm{H}$ & 0.65 & 3.0 \\
\hline 23 & $\mathrm{OH}$ & $\mathrm{OMe}$ & $\mathrm{OH}$ & $\mathrm{CH}_{2}-\mathrm{Ph}$ & $\mathrm{H}$ & 0.34 & 1.9 \\
\hline 24 & $\mathrm{OH}$ & $\mathrm{OMe}$ & $\mathrm{OMe}$ & $\mathrm{OMe}$ & $\mathrm{H}$ & 0.39 & 2.4 \\
\hline $25^{a)}$ & $\mathrm{OMe}$ & $\mathrm{OH}$ & $\mathrm{OMe}$ & $\mathrm{OMe}$ & $\mathrm{H}$ & 0.34 & 1.9 \\
\hline 26 (LARI 4) & $\mathrm{OMe}$ & $\mathrm{OMe}$ & $\mathrm{OMe}$ & $\mathrm{OMe}$ & $\mathrm{H}$ & 0.32 & 1.7 \\
\hline Quercitrin $^{a)}$ & $\mathrm{OH}$ & $\mathrm{H}$ & $\mathrm{OH}$ & $\mathrm{H}$ & $O$-L-Rham. ${ }^{b)}$ & 2.9 & 21 \\
\hline
\end{tabular}

a) Compounds 3 (cirsiliol), 8 (axillarin), 9 (7-methylaxillarin), and 25 (LARI 1) as well as quercitrin were assayed previously ${ }^{4)}$ and tested as references again in this study.

b) O-L-Rhamnosyl.

or little affected the inhibitory potency. On the other hand, methylation of the hydroxyl group at $\mathrm{C}_{8}$ clearly increased the inhibitory activity: 5,3',4'-trihydroxy-7,8-dimethoxyflavone (14) and $3^{\prime}, 4^{\prime}$-dihydroxy-5,7,8-trimethoxyflavone (17) were superior in potency to $5,8,3^{\prime}, 4^{\prime}$ tetrahydroxy-7-methoxyflavone (13) and 8,3',4'-trihydroxy-5,7-dimethoxyflavone (15), respectively. Methoxylation at $\mathrm{C}_{3}$ decreased or did not affect the inhibitory activity.

3) 3',4'-Dihydroxy-5,6,7,8-tetrasubstituted Flavones (21-26)-No definite conclusion was obtained on the effect of methylation of hydroxyl group(s) in ring A of this series of flavones. It appears, however, that the inhibitory activity of $3^{\prime}, 4^{\prime}$-dihydroxy-5,6,7,8-tetrasubstituted flavones tends to be augmented along with increasing degree of methylation of hydroxyl group(s) in ring A. This is exemplified by the findings that 5,6,3',4'-tetrahydroxy7,8-dimethoxyflavone (22), LARI 1 (25), and LARI 4 (26) were more potent than 5,6,7,3',4'pentahydroxy-8-methoxyflavone (21), compound (22), and 5,3',4'-trihydroxy-6,7,8-tri- 


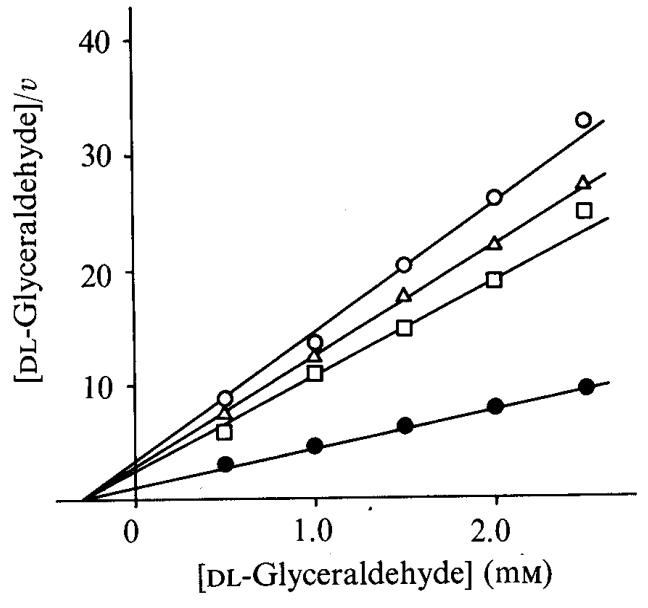

Fig. 1. Hanes-Woolf Plots of [DL-Glyceraldehyde] $/ v$ against [DL-Glyceraldehyde]

The assay of RLAR was performed in the presence and absence of an inhibitor $\left(5 \times 10^{-8} \mathrm{M}\right)$ as described in Materials and Methods except that the DLglyceraldehyde concentration was varied. (O) no inhibitor, $(\triangle)$ 8-benzyl-5,7,3',4'-tetrahydroxy-6methoxyflavone (23), ( $\square$ ) LARI 1 (25), (O) LARI 4 (26).

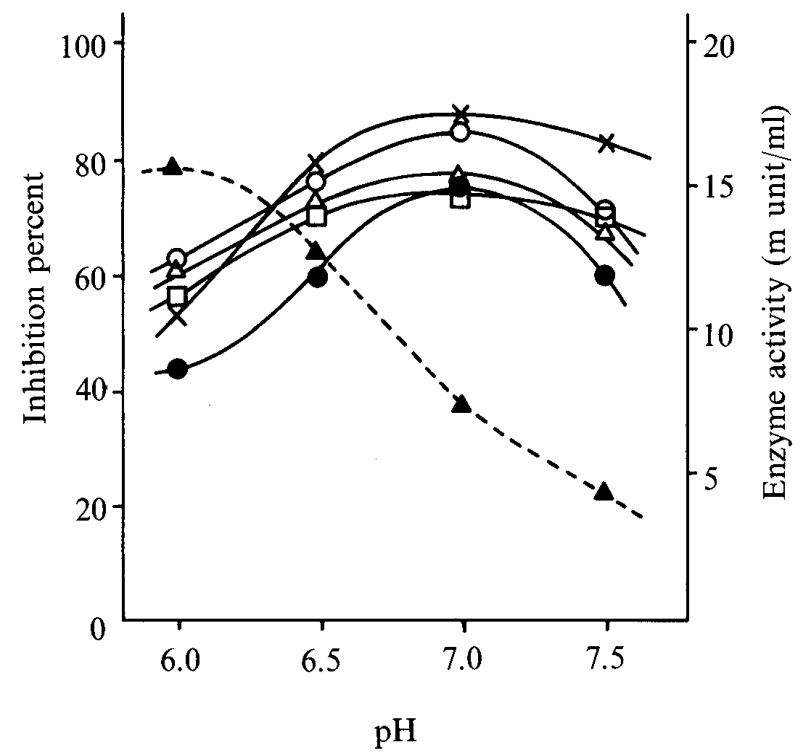

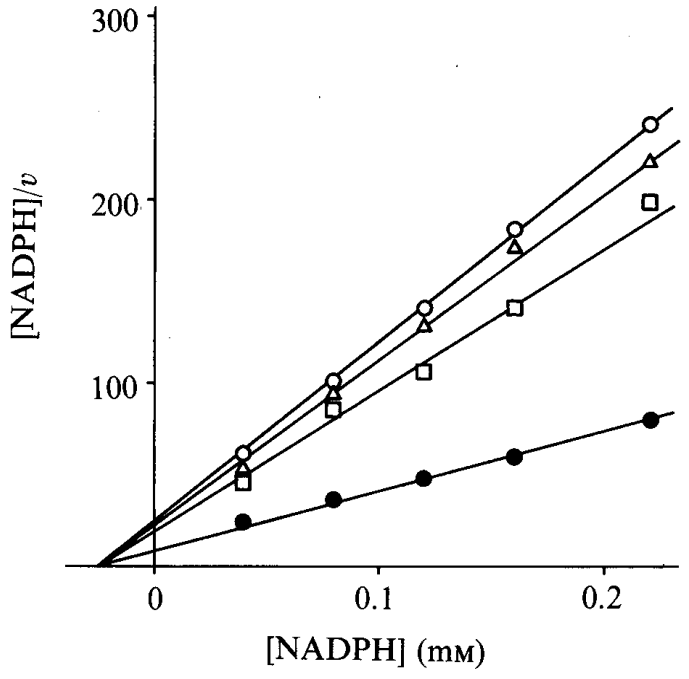

Fig. 2. Hanes-Woolf Plots of $[\mathrm{NADPH}] / v$ against [NADPH]

The assay of RLAR was performed in the presence and absence of an inhibitor $\left(5 \times 10^{-8} \mathrm{M}\right)$ as described in Materials and Methods except that the NADPH concentration was varied. $(\triangle)$ no inhibitor, $(\triangle)$ 8benzyl-5, 7, 3', $4^{\prime}$-tetrahydroxy-6-methoxyflavone (23), ( $\square)$ LARI 1 (25), (O) LARI 4 (26).

Fig. 3. Dependence on $\mathrm{pH}$ of the Inhibitory Activity of Flavones against RLAR

The assay of RLAR was performed in the presence and absence of an inhibitor $\left(5 \times 10^{-8} \mathrm{M}\right)$ as described in Materials and Methods. $(\times)$ axillarin $(8),(\mathbf{O})$ $3^{\prime}, 4^{\prime}$-dihydroxy-5,7,8-trimethoxyflavone $(\mathbf{1 7}),(\triangle) 8$ benzyl-5,7,3',4'-tetrahydroxy-6-methoxyflavone (23), ( $\square)$ LARI 1 (25), (O) LARI 4 (26). Aldose reductase activity in the absence of an inhibitor is shown by a broken line and expressed as $\mathrm{m}$ unit $/ \mathrm{ml}$ of the reaction mixture. Values of inhibition percent were calculated as percentages of the rate of enzyme activity at various $\mathrm{pH}$ values in the absence of inhibitor. Each point is the mean of 2 experiments.

methoxyflavone (24), respectively. It should be noted that 8-benzyl-5,7,3',4'-tetrahydroxy6-methoxyflavone (23), possessing a bulky substituent at $\mathrm{C}_{8}$, is rather potent.

\section{Kinetics of Inhibition of Aldose Reductase}

The inhibition of aldose reductase by flavones was found to be completely reversible from the dialysis experiments. Kinetic studies of the reversible inhibition were thus conducted to determine the nature of the inhibition of lens aldose reductase by flavones. The effect of varying the DL-glyceraldehyde concentration on the inhibition of RLAR and BLAR by flavones $\left(5 \times 10^{-8} \mathrm{M}\right)$ was investigated by graphing the kinetic data as Hanes-Woolf plots. These compounds exhibited non-competitive inhibition for both RLAR (Fig. 1) and BLAR (data not shown). The inhibitor constant $\left(K_{\mathfrak{i}}\right)$, for example, of LARI 4 (26) for RLAR was 
determined graphically to be $6 \times 10^{-8} \mathrm{M}$. The effect of varying the NADPH concentration on the inhibition by flavones was also investigated. Inhibition of RLAR (Fig. 2) and BLAR (data not shown) by flavones was also of a non-competitive type with respect to NADPH.

\section{Effect of pH on Inhibition of Aldose Reductase}

It seems to be of value to determine whether or not the inhibition of aldose reductase by flavone derivatives is influenced by $\mathrm{pH}$, because the intracellular $\mathrm{pH}$ is variable under various conditions. The effect of $\mathrm{pH}$ on the inhibition of RLAR by five $3^{\prime}, 4^{\prime}$-dihydroxyflavones including LARI 4 is indicated in Fig. 3. The inhibitory activities of these flavones tested were all $\mathrm{pH}$-dependent, being maximal around $\mathrm{pH} 7.0$ when the $\mathrm{pH}$ was varied within a range of 6.0 to 7.5 .

\section{Discussion}

Several classes of compounds of diverse structure are known to inhibit the enzyme aldose reductase, ${ }^{1,2 a, 4)}$ including a large number of flavonoids, e.g. quercitrin and myricitrin. ${ }^{1 a, b)}$ These studies prompted us to investigate the inhibitory activities of various $3^{\prime}, 4^{\prime}$-dihydroxyflavones. Of the 3',4'-dihydroxyflavones tested in this study, 3',4'-dihydroxy5,6,7,8-tetramethoxyflavone (LARI 4, 26) was the most potent inhibitor. Its activity was comparable to those of axillarin (8) and LARI 1 (25) (the most potent flavones previously reported). ${ }^{4}$

Varma and Kinoshita ${ }^{1 b}$ indicated some possible relationships of structure to the inhibitory potencies of flavonoids, and $\mathrm{we}^{4)}$ recently reported some additional structureactivity relationships of flavonoids. The present work demonstrates the effect of methylation of hydroxyl groups in ring A of $3^{\prime}, 4^{\prime}$-dihydroxyflavones. Our conclusions are as follows: (1) methylation of the hydroxyl group at either $\mathrm{C}_{5}$ or $\mathrm{C}_{6}$ increases or does not affect the inhibitory activity, (2) methylation of the 7-OH enhances the inhibitory activity of $3^{\prime}, 4^{\prime}$-dihydroxy-5,7,8trisubstituted and $3^{\prime}, 4^{\prime}$-dihydroxy-5,6,7,8-tetrasubstituted flavones, and (3) methylation of the $8-\mathrm{OH}$ potentiates the inhibitory activity. $\mathrm{We}^{4)}$ previously reported that methoxylation at $\mathrm{C}_{3}$ did not affect the inhibitory potency. However, we found in this study that methoxylation at $\mathrm{C}_{3}$ decreased the potency in 6 of 8 cases.

$\mathrm{We}^{10)}$ also reported previously that the inhibition of lens aldose reductase by hydantoin derivatives is $\mathrm{pH}$-dependent, and suggested that the inhibition by 1 -substituted hydantoins and by 5-substituted hydantoins is due to the non-ionized and ionized forms, respectively. The experiment on the effect of $\mathrm{pH}$ on aldose reductase inhibition by flavones revealed that the maximal inhibition occurs around $\mathrm{pH} 7.0$ (Fig. 3). The pH-inhibition curve of LARI 4 (26) does not seem to be explainable in terms of $\mathrm{pH}$-dependent structural change of this compound, in contrast to the case of hydantoin derivatives, because the $\mathrm{pH}$-inhibition relation shows a bell-shaped curve and moreover the $\mathrm{p} K$ value at $30^{\circ} \mathrm{C}$ (assay temperature) of LARI 4 (26) is supposed to be higher than 9.5 (the $\mathrm{p} K$ value of pyrocatechol at $20^{\circ} \mathrm{C}$ is $9.85^{11)}$ ). A possible explanation for the $\mathrm{pH}$-dependency of aldose reductase inhibition by LARI 4 (26) is that the inhibitory potency of this flavone (non-ionized form) correlates with net electric charges of aldose reductase. This explanation appears to be applicable to four other flavones, because their $\mathrm{pH}$-inhibition curves are similar to that of LARI 4 (26).

\section{References}

1) a) S. D. Varma, I. Mikuni, and J. H. Kinoshita, Science, 188, $1215(1975)$; b) S. D. Varma and J. H. Kinoshita, Biochem. Pharmacol., 25, 2505 (1976); c) A. B. Segelman, F. P. Segelman, S. D. Varma, H. Wagner, and O. Segligmann, J. Pharm. Sci., 66, 1358 (1977).

2) a) F. Fauran, C. Feniou, J. Mosser, and G. Prat, Eur. J. Med. Chem., 13, 503 (1978); b) K. H. Gabbay, N. Engl. 
J. Med., 288, 831 (1973); c) J. H. Kinoshita, S. D. Varma, and H. N. Fukui, Jpn. J. Ophthalmol., 20, 399 (1976); d) S. D. Varma, A. Mizuno, and J. H. Kinoshita, Science, 195, 205 (1977).

3) J. H. Kinoshita, P. F. Kador, and M. Catiles, J. Am. Med. Assoc., 246, 257 (1981).

4) J. Okuda, I. Miwa, K. Inagaki, T. Horie, and M. Nakayama, Biochem. Pharmacol, 31, 3807 (1982).

5) a) A. Ulubelen, K. M. Kerr, and T. J. Mabry, Phytochemistry, 19, 1761 (1980); b) I. Reiss-Maurer and H. Wagner, Symposium Papers, the 5th Hungarian Bioflavonoid Symposium, Matrüfured, Hungary, 1977, p. 187; c) K. Fukui, M. Nakayama, and T. Horie, Bull. Chem. Soc. Jpn., 42, 1649 (1969); d) T. Horie, Nippon Kagaku Kaishi, 1978, 748; e) K. Fukui, M. Nakayama, T. Matsui, M. Masumura, and T. Horie, ibid., 90, $1270(1969) ; f)$ S. Matsumura, T. Kunii, and A. Matsuura, Chem. Pharm. Bull., 21, 2757 (1973).

6) L. Farkas and M. Nógrádi, Tetrahedron Lett., 1966, 3759; M. Nakayama, K. Fukui, T. Horie, Y. Shimizu, and M. Masumura, Nippon Kagaku Kaishi, 91, 1174 (1970); T. Horie, H. Kourai, and N. Fujita, Bull. Chem. Soc. Jpn., 56, 3773 (1983).

7) M. Nakayama, I. Mori, and T. Horie, Nippon Kagaku Kaishi, 1983, 161; T. Horie, M. Tsukayama, M. Masumura, M. Nakayama, S. Hayashi, and K. Fukui, ibid., 1972, 773.

8) K. Inagaki, I. Miwa, and J. Okuda, Arch. Biochem. Biophys., 216, 337 (1982).

9) P. F. Kador, L. O. Merola, and J. H. Kinoshita, Doc. Ophthalmol. Proc. Series, 18, 117 (1979).

10) K. Inagaki, I. Miwa, T. Yashiro, and J. Okuda, Chem. Pharm. Bull., 30, 3244 (1982).

11) R. C. Weast (ed.), "Handbook of Chemistry and Physics," 54th ed., CRC Press, Cleveland, 1973, p. D-130. 